\title{
SEASONAL AND INTER-ANNUAL DECOMPOSITION, MICROBIAL BIOMASS, AND NITROGEN DYNAMICS IN A CANADIAN BOG
}

\author{
Nathan Basiliko', Tim R. Moore', Peter M. Lafleur2, and Nigel T. Roulet ${ }^{1,3}$
}

To establish the temporal and spatial variability of substrate contribution to ecosystem respiration (ER), we measured the seasonal and inter-annual microbial carbon dioxide $\left(\mathrm{CO}_{2}\right)$ production potential, microbial biomass, and nitrogen dynamics over a period of 2 years in the upper $30 \mathrm{~cm}$ of a peat bog in southern Ontario. Samples collected during a warmer year with lower average summer water table position had larger inorganic and organic nitrogen $(N)$ concentrations and microbial $\mathrm{CO}_{2}$ production potentials. Across all sampling dates, the distance of the water table beneath the surface was significantly and positively correlated with $\mathbf{N}$ availability, and in turn $\mathbf{N}$ availability was significantly and positively correlated with $\mathrm{CO}_{2}$ production, although direct correlation between water table position and $\mathrm{CO}_{2}$ production was only significant at $P=0.1$. Inter-seasonal variability in $\mathrm{CO}_{2}$ production, microbial biomass, or $\mathbf{N}$ did not follow consistent patterns between years, and inorganic $\mathbf{N}$ species, particularly nitrate, concentrations varied relatively the most between sampling dates, although concentrations were always small relative to microbial biomass $\mathrm{N}$ and potassium sulfateextractable organic $\mathrm{N}$. Microbial $\mathrm{CO}_{2}$ production from the surface peat profile was calculated to be between 2.5 and $5.7 \mathrm{~g} \mathrm{CO}_{2} \mathrm{~m}^{-2}$ day ${ }^{-1}$. Data extrapolation showed that microbial production of $\mathrm{CO}_{2}$ can be between 41 and $67 \%$ of the $\mathrm{CO}_{2}$ emitted as ER with the larger value falling in a warmer, drier year and that inter-annual changes in production potentials may partially explain increased ER in warmer, drier years. These results suggest that changes in microbial $\mathrm{CO}_{2}$ production and microbial community and nutrient characteristics may play an important role in controlling the emission of $\mathrm{CO}_{2}$ from terrestrial ecosystems such as peatlands. (Soil Science 2005;170:902-912)

Key words: Carbon dioxide, decomposition, microbial biomass nitrogen, peatland, respiration.

$\mathbf{N}$ ORTHERN peatlands have sequestered between 270 to $455 \mathrm{Pg} \mathrm{CO}_{2}-\mathrm{C}$ from the atmosphere and therefore play an important role in the global greenhouse effect (Gorham 1991;

'Department of Geography and Centre for Climate and Global Change Research, McGill University, 805 Sherbrooke St. West, Montreal, Quebec, Canada H3A 2K6. Dr. Basiliko is correspondins author, now at Department of Forest Sciences, University of British Columbia, 2424 Main Mall, Vancouver, British Columbia, Canada V6T 1Z4. E-mail: nathan.basiliko@ubc.ca

2Department of Geography, Trent University, 1600 Westbank Drive, P.O. Box 4800, Peterborough, Ontario, Canada K9J 7B8.

${ }^{3}$ McGill School of Environment, 3534 University Street, Montreal, Quebec, Canada, H3A 2A7

Received Dec. 5, 2004; accepted June 5, 2005.

DOI: 10.1097/01.ss.0000196765.59412.14
Turunen et al., 2002). Carbon sequestration results from an imbalance between primary production and organic matter decomposition, leading to the buildup of peat deposits that are often meters deep and contain up to $200 \mathrm{~kg} \mathrm{C} \mathrm{m}^{-2}$. Decomposition is slow in peatlands owing to poor substrate quality, limited nutrient supply, antimicrobial properties of the endemic plant tissues, primarily Sphagnum mosses, low $\mathrm{pH}$, and cold and at least partially waterlogged environments (Yavitt et al., 1997). Long-term C accumulation rates have been estimated using radioisotope-derived ages of basal peat and bulk densities (Gorham 1991; Turunen et al., 2002) but cannot resolve contemporary or short-term effects of climate and environmental changes. 
Net ecosystem $\mathrm{CO}_{2}$ exchange (NEE) has been measured with flux chamber and eddycovariance techniques over scales of $\mathrm{m}^{2}$ to ha at fine temporal resolution and can be partitioned into photosynthesis and ecosystem respiration (ER), the latter under dark conditions (e.g., Bubier et al., 2003, Lafleur et al., 2003). These techniques have been used to parameterize predictive models (Frolking et al., 2002), but they cannot separate ER into plant and microbial $\mathrm{CO}_{2}$ production components. Using separate measurement techniques at the Mer Bleue bog near Ottawa, Canada, both Bubier et al. (2003) and Lafleur et al. (2003) reported variability in $\mathrm{ER}$, driven by differences in temperature and moisture status, was primarily responsible for inter-annual differences in NEE.

Microbial decomposition is responsible for the net release of $\mathrm{C}$ from peat to the atmosphere, though it is inherently difficult to measure. Continuous Sphagnum moss cover and dense vascular roots inter-twined in the peat profile make in situ characterization of microbial $\mathrm{CO}_{2}$ production impossible due to concomitant plant respiration. One of the most common methods of characterizing microbial $\mathrm{CO}_{2}$ production involves removal of peat and in vitro incubation under controlled temperature and aeration in the absence of living vegetation (Blodau et al., 2004; Glatzel et al., 2004; Moore and Dalva, 1997; Yavitt et al., 1997). Often termed potential $\mathrm{CO}_{2}$ production, this technique can demonstrate or identify the effects of in situ peat chemical, nutrient, and microbial differences on $\mathrm{CO}_{2}$ production under controlled temperature and aeration. Samples are usually collected once to illustrate inter-site or treatment effects on microbial $\mathrm{CO}_{2}$ production. However, it is likely that peat chemistry and nutrients that affect microbial biomass and microbial $\mathrm{CO}_{2}$ production vary over time because of changes in temperature and precipitation and through plant activities, which provide a pool of labile organic matter and nutrients to microorganisms through exudation and fine root turnover. Thus, plant phenology, changing environmental conditions, and variations in nutrient availability could affect decomposition rates.

As there are apparently no studies that explore variations in seasonal and inter-annual heterotrophic $\mathrm{CO}_{2}$ production in peatlands, our objective was to characterize seasonal and interannual microbial $\mathrm{CO}_{2}$ production potential in a bog. We collected samples from the upper $30 \mathrm{~cm}$ of a peat profile at one site in the Mer Bleue bog over a period of 2 years and incubated the samples in the laboratory to determine $\mathrm{CO}_{2}$ production potential. We attempted to relate variations in $\mathrm{CO}_{2}$ production potential to differences in substrate characteristics and variations in thermal and hydrologic regime. We then relate these measurements to field observations of ER at the site.

\section{MATERIALS AND METHODS}

\section{Study Site, Environmental Measurements, and Peat Sampling}

Mer Bleue is a $25 \mathrm{~km}^{2}$ peatland complex located $10 \mathrm{~km}$ east of Ottawa, ON, Canada. Samples were taken from an ombrotrophic bog site that has previously been described in detail (Basiliko et al., 2004; Blodau et al., 2004; Bubier et al., 2003; Lafleur et al., 2003; Moore et al., 2002). The microtopography was dominated by hummocks with Chamaedaphne calyculata, Ledum groenlandicum and Kalmia angustifolium shrubs and Sphagnum capillifolium, Sphagnum magellanicum, and Polytrichum strictum mosses. Surface elevation between hummocks and hollows varied by about 10 to $20 \mathrm{~cm}$. Continuous measurements of water table position and peat temperature, relative to the peat surface, were made at the nearby eddy-covariance tower (see Lafleur et al., 2003, 2001, for details).

In mid June, August, and November 2000 and mid June, October, and December 2001, single $100 \mathrm{~cm}^{2} \times 35 \mathrm{~cm}$ cores were removed from five hummocks approximately $30 \mathrm{~m}$ northeast of the tower with a serrated knife, transported to the laboratory in coolers, and stored at $4{ }^{\circ} \mathrm{C}$. The surface vegetation, including green photosynthetic portions of the Sphagnum moss layer, was removed and cores were dissected into 0 - to 5-, 5- to $10-, 10-$ to $20-$, and 20- to $30-\mathrm{cm}$ depth segments.

\section{Analytical Methods}

Incubations were set up 48 hours after sampling to eliminate residual plant root respiration. Approximately $5 \mathrm{~g}$ of peat (wet weight) from each sample was placed into a 50-ml Erlenmeyer flask. Twenty milliliters of deionized water was added to create a slurry that helped to eliminate any local regions of anoxia in the peat. Flasks were capped with silicon filled rubber Suba seals (William Freeman Ltd, Barnsley, UK) and shaken on a rotary shaker at $200 \mathrm{rpm}$ for 2 days at $21{ }^{\circ} \mathrm{C}$. After the incubation, the $\mathrm{pH}$ of the slurry was measured potentiometrically (Watertest AgS/glass-electrode, Hanna Instruments, 
Woonsocket, RI, USA) with an Orion meter (Thermo Electron Corp., Waltham, MA, USA), headspace volume was determined by displacement with water, and flasks were dried at $70{ }^{\circ} \mathrm{C}$ to measure the dry weight of peat. During the incubation, headspace air was sampled at least three times with syringes and needles and analyzed for $\mathrm{CO}_{2}$ using a Shimadzu Mini II (Shimadzu, Kyoto, Japan) gas chromatograph equipped with a methanizer, Porapak Q column with 80/100 mesh (Alltech, Deerfield IL, USA) maintained at $40{ }^{\circ} \mathrm{C}$, and flame ionization detector maintained at $100{ }^{\circ} \mathrm{C}$. Concentrations were determined relative to commercial standards (350, 2040, and 9940 ppmv). Fluxes were calculated as the volume corrected linear increase in $\mathrm{CO}_{2}$ over time per g dry peat. Values are expressed per $\mathrm{g}$ dry peat or per $\mathrm{m}^{2}$ by $30 \mathrm{~cm}$ volume of peat after conversion using dry bulk density values for the Mer Bleue bog of 36, 41, 36 , and $42 \mathrm{mg} \mathrm{cm}^{-3}$ for the 0 - to 5-, 5- to $10-$, $10-$ to $20-$, and $20-$ to $30-\mathrm{cm}$ depth segments (J. Turunen, personal communication).

Extractable organic and microbial $\mathrm{C}$ and $\mathrm{N}$ and inorganic $\mathrm{N}$ were determined using a chloroform $\left(\mathrm{CHCl}_{3}\right)$ fumigation-extraction technique modified from Voroney et al. (1993). Briefly, approximately $40 \mathrm{~g}$ of peat (wet weight) from each bulk sample was split into two $20 \mathrm{~g}$ samples. One sample was placed in a vacuum desiccator and fumigated with ethanol-free $\mathrm{CHCl}_{3}$ in absence of light for 24 hours. Chloroform vapor and residue was then removed through repeated evacuation. All samples were sealed in containers containing $0.5 \mathrm{M}$ potassium sulfate $\left(\mathrm{K}_{2} \mathrm{SO}_{4}\right)$ solution, shaken for 1 hour at $200 \mathrm{rpm}$ on an oscillating shaker, and filtered with $0.45-\mu \mathrm{m}$ glass fiber filters. A subsample of each extract was used in an alkaline persulfate oxidation reaction to determine total $\mathrm{N}$ in solution as $\mathrm{NO}_{3}{ }^{-}$(Williams et al., 1995). Dissolved inorganic N (DIN) was measured as $\mathrm{NH}_{4}{ }^{+}$and $\mathrm{NO}_{2}+\mathrm{NO}_{3}{ }^{-}$colorimetrically on a Latchat FIA 8000 series continuous flow autoanalyzer (Latchat Instruments, Milwaukee, WI, USA). Dissolved organic C (DOC) was measured with a Shimadzu 5050 TOC analyzer after $\mathrm{pH}$ adjustment to 2.5 and sparging with $\mathrm{CO}_{2}$-free $\mathrm{N}_{2}$ for 10 minutes. Extractable DOC and DIN were measured directly in $\mathrm{K}_{2} \mathrm{SO}_{4}$ extracts from the nonfumigated samples. Extractable organic $\mathrm{N}$ was calculated as total extractable $\mathrm{N}$ from the nonfumigated subsamples minus DIN. Microbial biomass $\mathrm{C}$ and $\mathrm{N}$ were calculated by subtracting the nonfumigated extractable
DOC or total $\mathrm{N}$ from the fumigation-extraction DOC or total $\mathrm{N}$, respectively. Because we were only interested in relative comparison between samples, and because there have been reports of large variations in $\mathrm{C}$ and $\mathrm{N}$ extraction efficiency coefficients $\left(\mathrm{K}_{\mathrm{EC}}, \mathrm{K}_{\mathrm{EN}}\right)$ (e.g., Brookes et al., 1985; Sparling et al., 1990) for different soils, no extraction efficiency coefficients were used in our calculations. Values are expressed per $g$ of dry peat and per $\mathrm{m}^{2}$ by $30 \mathrm{~cm}$ depth volume of peat as above. The sum of all pools of $\mathrm{N}$ characterized is referred to as total $\mathrm{N}$.

Respiration quotients $\left(q \mathrm{CO}_{2}\right)$ were calculated as the rate of $\mathrm{CO}_{2}-\mathrm{C}$ production per microbial biomass $\mathrm{C}$ per day. Temperaturecorrected $\mathrm{CO}_{2}$ production rates were calculated using $\mathrm{Q}_{10}$ values reported in Scanlon and Moore (2000) for the same site to estimate in situ rates of $\mathrm{CO}_{2}$ production. We applied the $\mathrm{Q}_{10} \mathrm{CO}_{2}$ production rate multiplier to the temperature difference between the daily temperature on the sampling day and the $22{ }^{\circ} \mathrm{C}$ temperature in the laboratory. Gravimetric moisture content was calculated as the proportion of moisture per dry peat, expressed as percent.

\section{Statistical Analyses}

All statistical calculations were made using Systat 10 (SPSS Inc. Chicago, IL, USA). Analysis of variance with Tukey post hoc testing was conducted to evaluate differences over time, over time at constant depths, or throughout depths at each date. Pearson correlation coefficients and corresponding Bonferroni probabilities were calculated between measured variables across all times and depths. For analysis of variance with the entire $\mathrm{NO}_{3}{ }^{-}, \mathrm{NH}_{4}{ }^{+}$, and temperature-corrected $\mathrm{CO}_{2}$ production data sets and the 0 - to $5-\mathrm{cm}$ depth $\mathrm{CO}_{2}$ production data set, where residual distribution was not normal (skewness/standard error of skewness and kurtosis/standard error of kurtosis $>2$ or $<-2$ ), data were $\log$ transformed and reanalyzed; however, for ease of interpretation, means and standard deviations of nontransformed data are presented. Significant differences are assumed at $P \leq 0.05$.

\section{RESULTS}

During the summer and fall of 2000 , the water table remained above about $40 \mathrm{~cm}$ beneath hummock surfaces, whereas it fell to a depth of about $70 \mathrm{~cm}$ during the summer of 2001 (Fig. 1A). Average water table depths at sampling times were $35 \mathrm{~cm}$ below the hummock surfaces 
in 2000 and $41 \mathrm{~cm}$ in 2001. Best-fit regressions of peat temperature indicated that peat was warmer by about $2{ }^{\circ} \mathrm{C}$ in 2001 than 2000 throughout depths (Fig. 1, B, C, and D), although across all sampling dates, temperatures were not significantly different between the 2 years. Peat moisture content did not vary significantly between the three sampling dates in 2000 and 2001, whereas pH decreased slightly and significantly in 2001 (Table 1).

Average $\mathrm{CO}_{2}$ production was significantly greater in 2001 (Table 1) and was correlated significantly and positively with extractable DOC, $\mathrm{NH}_{4}{ }^{+}, \mathrm{NO}_{3}{ }^{-}$, and DON (Table 2), all of which also increased significantly in 2001 (Table 1). Water table depth at time of sampling was negatively, though not significantly, correlated with extractable DOC and negatively correlated with $\mathrm{CO}_{2}$ production potential at $P=0.10$ but showed a significant negative correlation with $\mathrm{NH}_{4}{ }^{+}, \mathrm{NO}_{3}{ }^{-}$and total $\mathrm{N}$ (Table 2). Average microbial $\mathrm{C}$ was not significantly larger in 2001, although microbial N increased significantly, resulting in a significantly lower microbial biomass $\mathrm{C}: \mathrm{N}$ quotient (Table 1). Microbial $\mathrm{C}$ and $\mathrm{N}$ were positively correlated with $\mathrm{CO}_{2}$ production, though relations were not significant (Table 2). No measured microbial or nutrient characteristics varied significantly with peat moisture content, whereas only microbial $\mathrm{N}$ decreased with increasing temperatures, and organic $\mathrm{N}$ and organic $\mathrm{C}: \mathrm{N}$ quotient varied with $\mathrm{pH}$ (Table 2). Temperature-corrected $\mathrm{CO}_{2}$ production rates were approximately one-half nonadjusted rates and were not significantly different between years (Table 1).

Average rates of $\mathrm{CO}_{2}$ production decreased from June through November 2000, though were only significantly larger in June 2000 (Fig. 2A), whereas microbial biomass $\mathrm{C}$ and $\mathrm{N}$ were significantly greater in November (Fig. 2, $\mathrm{C}$ and $\mathrm{H}$ ). The microbial $\mathrm{C}: \mathrm{N}$ quotient did not change significantly throughout 2000 (Fig. 2K). Decreasing $\mathrm{CO}_{2}$ production and increasing microbial biomass over 2000 led to decreasing $q \mathrm{CO}_{2}$, though as with $\mathrm{CO}_{2}$ production, quotients were only significantly larger in June 2000 (Fig. 2I). Similar patterns were not observed in 2001, and there were no other clear or consistent inter-seasonal patterns of measured microbial or nutrient characteristics (Fig. 2). Microbial $\mathrm{CO}_{2}$ production varied from $2.5 \mathrm{~g}$ $\mathrm{CO}_{2} \mathrm{~m}^{-2} \mathrm{day}^{-1}$ in November 2000 to $5.7 \mathrm{~g}$ $\mathrm{CO}_{2} \mathrm{~m}^{-2}$ day $^{-1}$ in June 2001(Fig. 2A), and microbial $\mathrm{C}$ varied from $26 \mathrm{~g} \mathrm{C} \mathrm{m}^{-2}$ in June to
$42 \mathrm{~g} \mathrm{C} \mathrm{m}^{-2}$ in November 2000 (Fig. 2C). The maximum relative difference in $\mathrm{N}$ over time was for $\mathrm{NO}_{3}-\mathrm{N}$ between November 2000 and June 2001 (Fig. 2E), followed by $\mathrm{NH}_{4}-\mathrm{N}$ between August 2000 and October 2001 (Fig. 2F), whereas extractable organic and microbial $\mathrm{N}$ varied relatively less among sampling dates (Fig. 2, $\mathrm{G}$ and $\mathrm{H}$ ). Although inorganic $\mathrm{N}$ changed relatively the most among sampling dates, total $\mathrm{N}$ was consistently dominated by microbial $\mathrm{N}$ followed by extractable organic $\mathrm{N}$. Temperature adjusted microbial $\mathrm{CO}_{2}$ production rates ranged from 0.2 and $0.4 \mathrm{~g} \mathrm{CO}_{2} \mathrm{~m}^{-2} \mathrm{day}^{-1}$ in November 2000 and December 2001 to a maximum of nearly $3 \mathrm{~g} \mathrm{CO}_{2} \mathrm{~m}^{-2} \mathrm{day}^{-1}$ in August 2000 and $5 \mathrm{~g} \mathrm{CO}_{2} \mathrm{~m}^{-2}$ day $^{-1}$ in June 2001. Temperature adjusted $\mathrm{CO}_{2}$ production decreased over time in 2001, though this trend was not as clear in 2000 (Fig. 2B).

Although there were not consistent patterns of microbial $\mathrm{CO}_{2}$ production and biomass $\mathrm{C}$ decreasing significantly with each depth, in most cases the surface depth was significantly greater than the lowest depth (Fig. 3, A and B). The pattern of decreasing $\mathrm{CO}_{2}$ production from June to November 2000 observed among depths (Fig. 2A) was most apparent at the surface, with rates at each date significantly different than the other two (Fig. 3A). Carbon dioxide production in the 5- to 10- and 20- to 20-cm segments in June 2000 was only significantly greater than November and August and November respectively, whereas in the $20-$ to $30-\mathrm{cm}$ segment, there were no significant differences over time (Fig. 3A). In contrast, the pattern of increasing microbial C over 2000 was not significant at the surface depth segment, while appearing between June and August and November in the 5to $10-\mathrm{cm}$ segment or June and November in the $20-$ to 30-cm segment (Fig. 3B). In 2001 there were no significant differences in microbial $\mathrm{CO}_{2}$ production or microbial $\mathrm{C}$ over time at any depths (Fig. 3, A and B). At all depths and sampling dates, microbial and extractable organic $\mathrm{N}$ dominated total measured $\mathrm{N}$ (Table 3 ). Clear depth patterns of individual nutrient pools over time were not apparent; although total $\mathrm{N}$ was significantly greater in the surface depth segment than the $10-$ to $20-$ and $20-$ to $30-\mathrm{cm}$ segment at all sampling dates except August 2000 and December 2001 (Table 3).

\section{DISCUSSION}

Microbial $\mathrm{CO}_{2}$ production rates were faster at three sampling dates during warmer and drier 
day of year
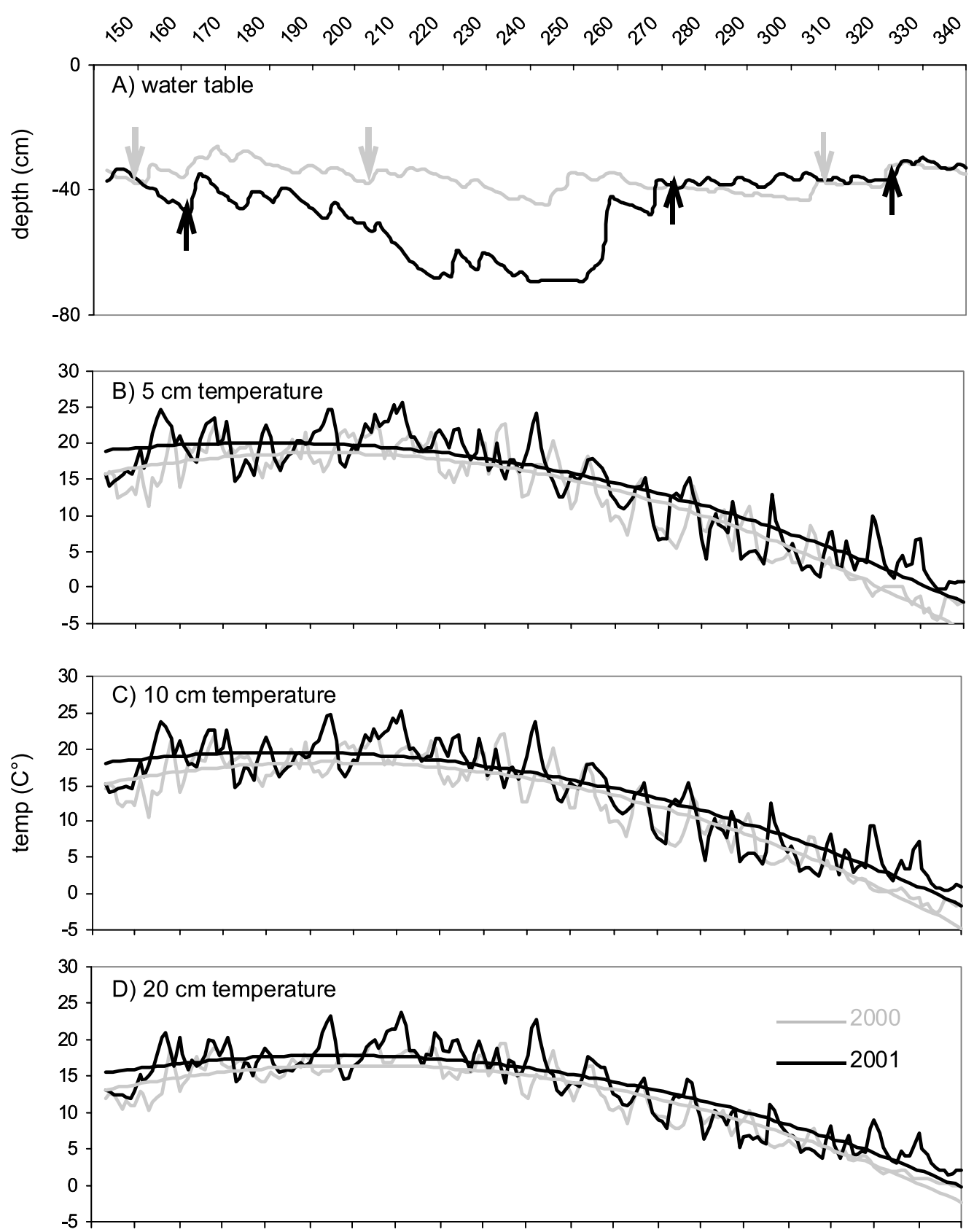

Fig. 1. Average daily water table positions below the surface of bog hummocks in late spring through autumn 2000 and 2001 and sampling dates indicated with arrows (A). Average daily peat temperatures at depths fit with second order polynomial regressions (B through D).

2001 than in 2000 at Mer Bleue. Enhanced decomposition has been demonstrated previously in peatlands experiencing water table drawdowns (Blodau et al., 2004; Moore and Dalva
1993), and Updegraff et al. (1996) reported that increased aeration led to increased mineralization of labile pools of $\mathrm{C}$ and $\mathrm{N}$. Although water table position only correlated with microbial $\mathrm{CO}_{2}$ 
TABLE 1

Average $\mathrm{CO}_{2}$ production potential, microbial biomass, $\mathrm{N}$, and $\mathrm{pH}$ in 2000 and 2001 for the upper 0 to $30 \mathrm{~cm}$ of the peat profile

\begin{tabular}{|c|c|c|}
\hline \multirow{2}{*}{ Property } & \multicolumn{2}{|c|}{ Year } \\
\hline & 2000 & 2001 \\
\hline $\begin{array}{l}\mathrm{CO}_{2} \text { production } \\
\quad\left(\mathrm{g} \mathrm{CO}_{2} \mathrm{~m}^{-2} \text { day }^{-1}\right)^{\dagger}\end{array}$ & $3.6(1.4)$ & $4.9(1.0)$ \\
\hline Temperature-corrected & $1.8(1.3)$ & $2.5(2.0)$ \\
\hline \multicolumn{3}{|l|}{$\begin{array}{l}\mathrm{CO}_{2} \text { production } \\
\quad\left(\mathrm{g} \mathrm{CO}_{2} \mathrm{~m}^{-2} \text { day }^{-1}\right)\end{array}$} \\
\hline Extractable DOC $\left(\mathrm{g} \mathrm{m}^{-2}\right)^{\dagger}$ & $16(3.5)$ & $22(3.9)$ \\
\hline Microbial C $\left(\mathrm{g} \mathrm{m}^{-2}\right)$ & $32(9.0)$ & $35(5.0)$ \\
\hline $\mathrm{NO}_{3}-\mathrm{N}\left(\mathrm{g} \mathrm{m}^{-2}\right)^{\dagger}$ & $0.02(0.01)$ & $0.17(0.15)$ \\
\hline $\mathrm{NH}_{4}-\mathrm{N}\left(\mathrm{g} \mathrm{m}^{-2}\right)^{\dagger}$ & $0.04(0.01)$ & $0.22(0.17)$ \\
\hline Extractable DON $\left(\mathrm{g} \mathrm{m}^{-2}\right)^{\dagger}$ & $0.76(0.17)$ & $1.4(0.26)$ \\
\hline Microbial $\mathrm{N}\left(\mathrm{g} \mathrm{m}^{-2}\right)^{\dagger}$ & $2.4(0.87)$ & $3.4(0.37)$ \\
\hline Total $N\left(\mathrm{~g} \mathrm{~m}^{-2}\right)^{\dagger}$ & $2.8(1.2)$ & $5.2(.38)$ \\
\hline Microbial C: $\mathrm{N}^{\dagger}$ & $13(2.2)$ & $10(1.1)$ \\
\hline Extractable organic C:N* & $20(5.8)$ & $16(2.0)$ \\
\hline $\mathrm{pH}^{\dagger}$ & $4.2(0.09)$ & $4.0(0.11)$ \\
\hline $\begin{array}{l}\text { Gravimetric moisture } \\
\text { content }(\%)\end{array}$ & $767(232)$ & $813(126)$ \\
\hline
\end{tabular}

Temperature-corrected $\mathrm{CO}_{2}$ production values were calculated by applying $\mathrm{Q}_{10}$ temperature multipliers from Scanlon and Moore (2000) to correct for temperature differences in situ at sampling and in the laboratory. Standard deviations of five replicate cores are in parentheses. Significant differences, ${ }^{*} P<0.05,{ }^{\dagger} P<0.01$.

production at $P=0.1$, a lower water table was significantly $(P<0.05)$ associated with an increase in concentrations of $\mathrm{NO}_{3}{ }^{-}, \mathrm{NH}_{4}{ }^{+}$, and total $\mathrm{N}$. In turn, microbial $\mathrm{CO}_{2}$ production was positively and significantly correlated with these labile pools, suggesting that a link may exist between $\mathrm{N}$ availability and microbial decomposition, though it is important to note that significant correlation coefficients were generally low ( 0.35 to
0.69), suggesting other or multiple factors controlled $\mathrm{N}$ availability and microbial activity. In a dry year, more $\mathrm{N}$ is available either through decreased plant uptake resulting from drought stress or enhanced transfer of $\mathrm{N}$ to the extractable or inorganic forms. As shrub biomass and productivity at Mer Bleue is greatest where the water table is lowest (Moore et al., 2002), the latter is more likely. Increased microbial biomass $\mathrm{N}$ in 2001 was not accompanied by increased microbial biomass $\mathrm{C}$, which led to smaller microbial $\mathrm{C}: \mathrm{N}$ quotients, perhaps indicating that increased $\mathrm{N}$ availability to microorganisms allowed for enhanced $\mathrm{CO}_{2}$ production. Although speculative, decreased C:N quotients could reflect a decrease in relative proportion of fungal, or an increase in the relative proportion of bacterial, biomass (Paul and Clark 1996). Increased microbial activity, yet no increase in biomass $\mathrm{C}$ between the two years, may corroborate this assumption, based on conclusions of Holland and Coleman (1987), who describe soil fungi as assimilating more, and respiring less, $\mathrm{C}$ than bacteria.

Contrary to water table depth, gravimetric peat moisture content did not correlate with nutrient concentrations, and inter-annual differences in peat moisture content were not significant. This probably was caused by sampling peat immediately after, though not during, the large water table drawdown in 2001, and to not having sampled peat on the same dates each year. Although there were no significant differences in moisture contents, it was likely that peat nutrient, chemical, and microbial properties measured in vitro still resulted from relatively wet and dry conditions between years. As with moisture content, there were no clear correlations

TABLE 2

Pearson correlation coefficients for factors measured across all depths and sampling dates

\begin{tabular}{lccccc}
\hline & Temperature & Water table & $\mathrm{pH}$ & Moisture content & $\mathrm{CO}_{2}$ production \\
\hline Moisture content & 0.038 & 0.050 & -0.022 & 1.000 & -0.22 \\
$\mathrm{CO}_{2}$ production & 0.203 & -0.300 & -0.101 & -0.045 & 1.000 \\
DOC & -0.225 & -0.217 & -0.267 & -0.092 & $0.474^{\dagger}$ \\
Microbial C & -0.215 & -0.136 & -0.042 & 0.168 & 0.301 \\
$\mathrm{NO}_{3}{ }^{-}$ & 0.193 & $-0.686^{\dagger}$ & -0.023 & 0.008 & $0.441^{\dagger}$ \\
$\mathrm{NH}_{4}{ }^{+}$ & 0.142 & $-0.370^{\dagger}$ & -0.286 & -0.005 & $0.440^{\dagger}$ \\
Organic N & -0.199 & -0.277 & $-0.330^{*}$ & 0.037 & $0.433^{\dagger}$ \\
Total N & -0.282 & $-0.397^{\dagger}$ & -0.274 & 0.033 & $0.349^{*}$ \\
Microbial N & $-0.335^{*}$ & -0.284 & -0.180 & -0.073 & 0.169 \\
Organic C:N & 0.071 & 0.307 & $0.396^{*}$ & -0.226 \\
Microbial C:N & 0.190 & 0.290 & 0.272 & -0.167 & 0.036 \\
\hline
\end{tabular}

Significant relationships, ${ }^{*} P<0.05,{ }^{\dagger} P<0.01$. 

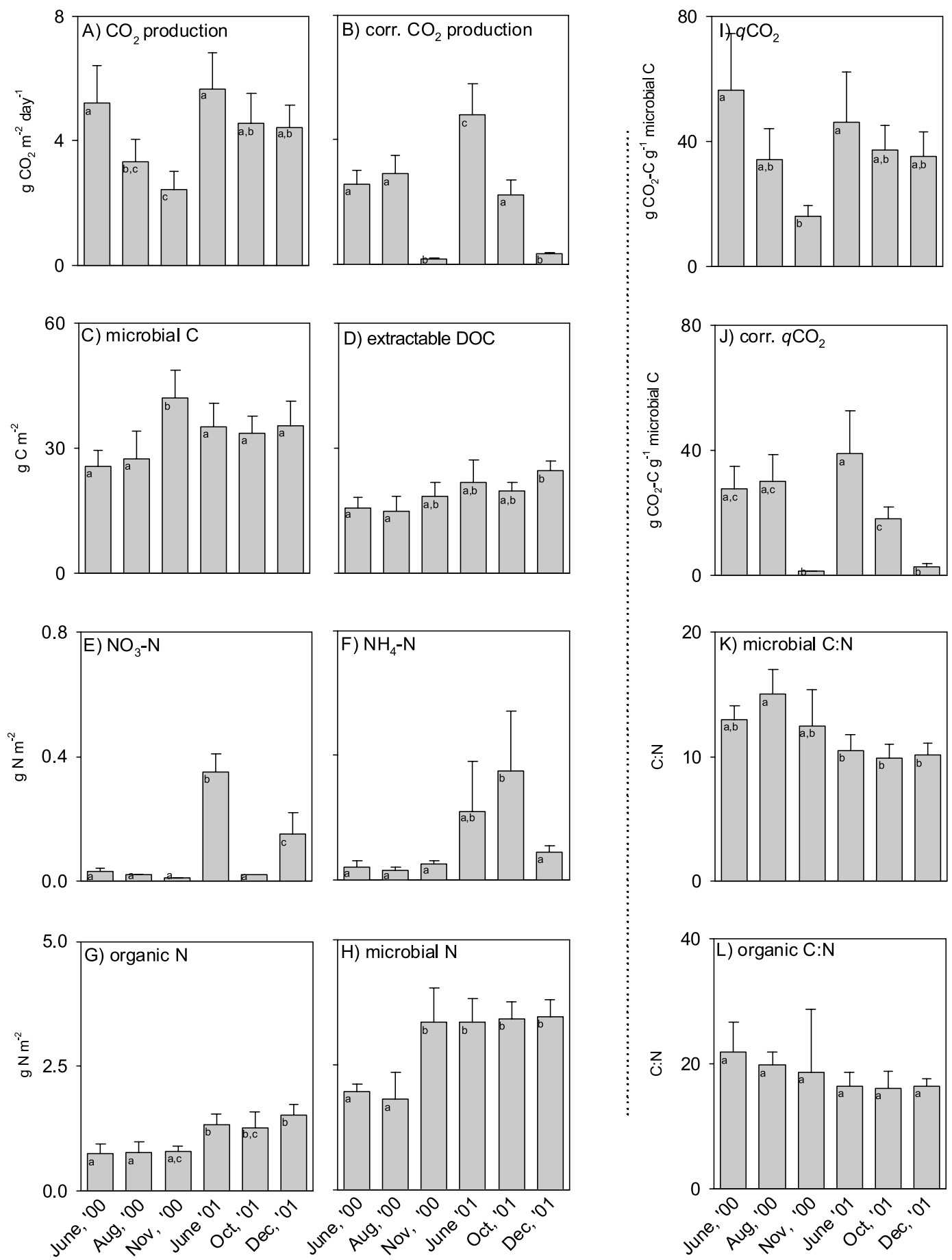

Fig. 2. Volumetric $\left(1 \mathrm{~m}^{2}\right.$ by $\left.30 \mathrm{~cm}\right) \mathrm{CO}_{2}$ production, microbial biomass, and $\mathrm{N}$ dynamics in 2000 and 2001. Corrected $\mathrm{CO}_{2}$ production (B) was calculated by applying $\mathrm{Q}_{10}$ temperature multipliers from Scanlon and Moore (2000) to correct for temperature differences in situ at sampling and in the laboratory. Bars represent standard deviations of five replicate cores. Significant differences $(P<0.05)$ between dates are indicated with different letters. 
A) $\mathrm{CO}_{2}$ production
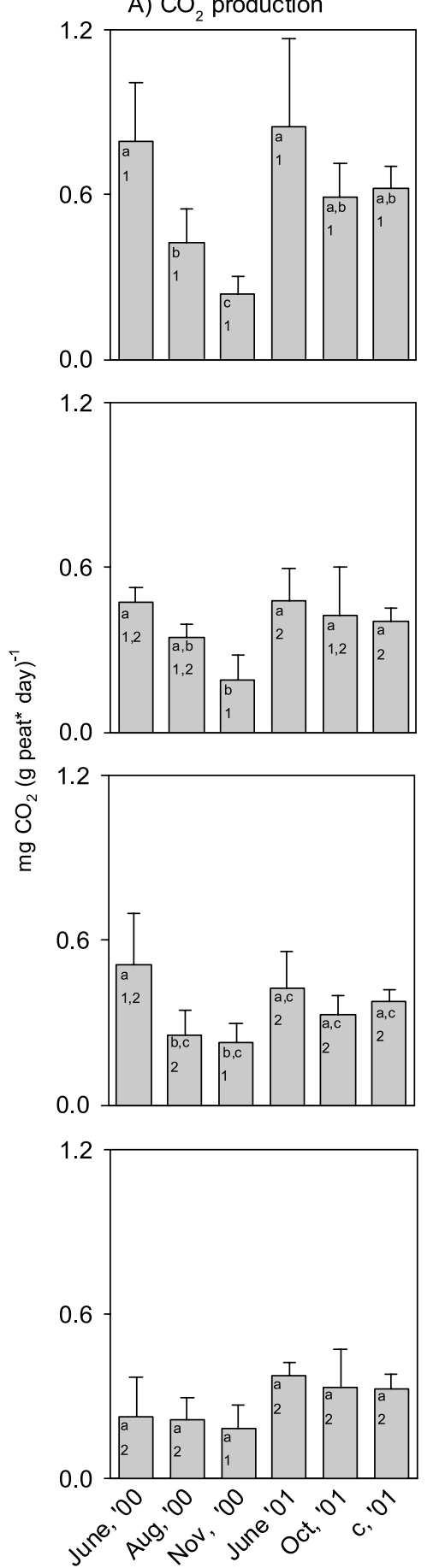

B) Microbial biomass $\mathrm{C}$
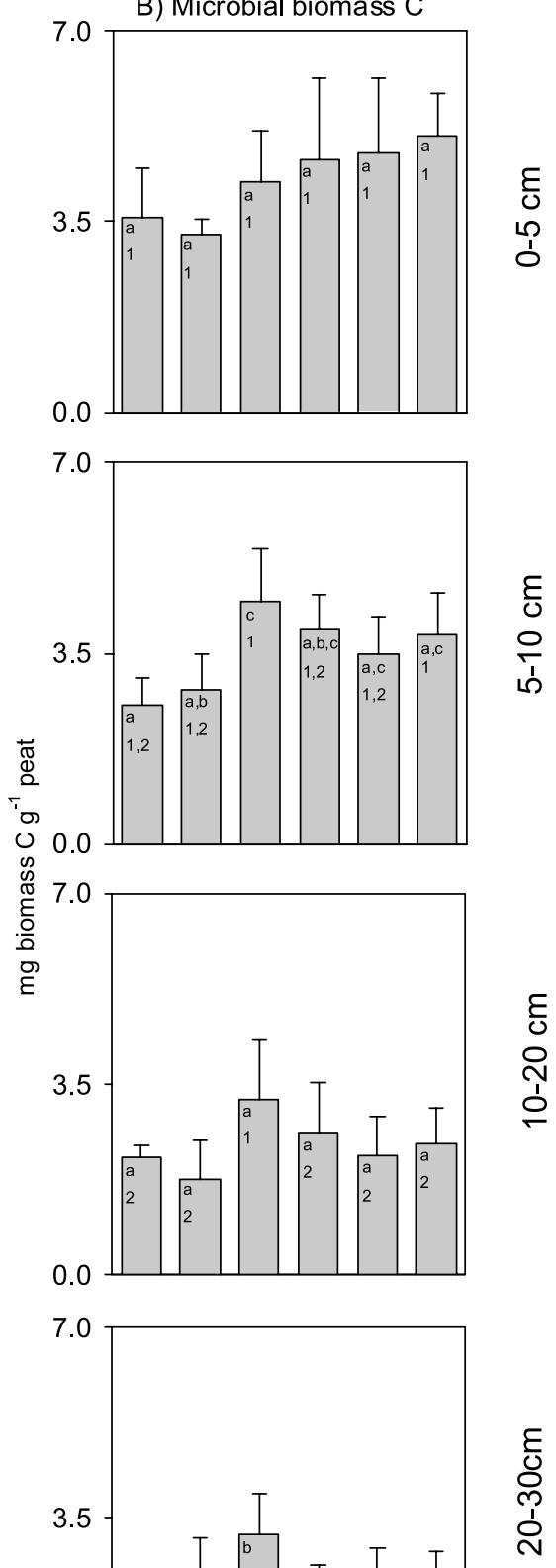

$\varepsilon$
0
0
0

$\frac{8}{0}$

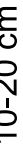

ঠे
లి
○े

Fis. 3. Carbon dioxide production potential and microbial biomass $\mathrm{C}$ across depth sesments and sampling dates. Bars represent standard deviations of five replicates. Significant differences $(P<0.05)$ between dates at each depth are indicated with different letters. Significant differences between depths at each date are indicated with different numbers. 
TABLE 3

Inorganic, organic (Org), and microbial (Mic) $\mathrm{N}$ across depth segments and sampling dates

\begin{tabular}{|c|c|c|c|c|c|c|}
\hline & June 2000 & Aug 2000 & Nov 2000 & June 2001 & Oct 2001 & Dec 2001 \\
\hline \multicolumn{7}{|c|}{$0-5 \mathrm{~cm}$} \\
\hline $\mathrm{NO}_{3}-\mathrm{N}$ & $4.31^{\mathrm{a}, \mathrm{b}}$ & $1.14^{\mathrm{a}}$ & $1.05^{\mathrm{a}}$ & $35.5^{\mathrm{b}}$ & $1.78^{\mathrm{a}}$ & $20.6^{\mathrm{b}}$ \\
\hline $\mathrm{NH}_{4}-\mathrm{N}$ & $8.83^{\mathrm{a}, \mathrm{b}}$ & $4.30^{\mathrm{a}}$ & $9.72^{\mathrm{a}, \mathrm{b}}$ & $48.0^{\mathrm{b}, \mathrm{c}}$ & $55.8^{\mathrm{c}}$ & $8.80^{\mathrm{a}}$ \\
\hline Org-N & $101^{\mathrm{a}, \mathrm{b}}$ & $63.1^{\mathrm{a}}$ & $124^{\mathrm{a}, \mathrm{b}}$ & $158^{\mathrm{a}, \mathrm{b}}$ & $192^{\mathrm{b}}$ & $144^{\mathrm{a}, \mathrm{b}}$ \\
\hline Mic-N & $213^{\mathrm{a}, \mathrm{b}}$ & $204^{a}$ & $410^{c}$ & $406^{c}$ & $381^{b, c}$ & $385^{\mathrm{b}, \mathrm{c}}$ \\
\hline Total N & $327^{1}$ & $273^{1}$ & $\begin{array}{l}545^{1} \\
\quad 5-10 \mathrm{~cm}\end{array}$ & $648^{1}$ & $631^{1}$ & $558^{1}$ \\
\hline $\mathrm{NO}_{3}-\mathrm{N}$ & $2.46^{\mathrm{a}, \mathrm{b}}$ & $1.82^{\mathrm{a}}$ & $1.17^{\mathrm{a}}$ & $26.1^{\mathrm{b}}$ & $1.50^{\mathrm{a}}$ & $14.5^{\mathrm{b}}$ \\
\hline $\mathrm{NH}_{4}-\mathrm{N}$ & $4.48^{\mathrm{a}}$ & $4.93^{\mathrm{a}}$ & $9.63^{\mathrm{a}}$ & $24.8^{\mathrm{a}}$ & $17.4^{a}$ & $11.6^{\mathrm{a}}$ \\
\hline Org-N & $60.8^{\mathrm{a}, \mathrm{b}}$ & $56.8^{\mathrm{b}}$ & $103^{a, b, c}$ & $114^{\mathrm{a}, \mathrm{c}}$ & $76.2^{\mathrm{a}, \mathrm{b}}$ & $152^{\mathrm{c}}$ \\
\hline Mic-N & $171^{\mathrm{a}, \mathrm{b}}$ & $137^{\mathrm{a}}$ & $456^{\mathrm{c}}$ & $294^{\mathrm{b}, \mathrm{c}}$ & $334^{c}$ & $341^{c}$ \\
\hline Total N & $239^{2}$ & $201^{1}$ & $\begin{array}{l}570^{1} \\
10-20 \mathrm{~cm}\end{array}$ & $459^{1,2}$ & $429^{2}$ & $519^{1}$ \\
\hline $\mathrm{NO}_{3}-\mathrm{N}$ & $3.87^{\mathrm{a}}$ & $2.17^{\mathrm{a}, \mathrm{b}}$ & $0.93^{\mathrm{b}}$ & $28.2^{c}$ & $1.78^{\mathrm{a}, \mathrm{b}}$ & $12.4^{\mathrm{d}}$ \\
\hline $\mathrm{NH}_{4}-\mathrm{N}$ & $4.00^{\mathrm{a}}$ & $4.56^{\mathrm{a}}$ & $3.61^{\mathrm{a}}$ & $11.1^{\mathrm{a}, \mathrm{b}}$ & $39.1^{\mathrm{b}}$ & $6.73^{\mathrm{a}}$ \\
\hline Org-N & $51.9^{\mathrm{a}}$ & $52.8^{\mathrm{a}}$ & $47.3^{\mathrm{a}}$ & $85.5^{\mathrm{a}, \mathrm{b}}$ & $110^{\mathrm{b}}$ & $112^{\mathrm{b}}$ \\
\hline Mic-N & $155^{\mathrm{a}, \mathrm{b}}$ & $96.8^{\mathrm{a}}$ & $200^{\mathrm{a}, \mathrm{b}}$ & $292^{\mathrm{b}}$ & $234^{\mathrm{b}}$ & $258^{\mathrm{b}}$ \\
\hline Total N & $215^{2}$ & $156^{1}$ & $\begin{array}{l}252^{2} \\
20-30 \mathrm{~cm}\end{array}$ & $417^{2}$ & $385^{2}$ & $389^{1}$ \\
\hline $\mathrm{NO}_{3}-\mathrm{N}$ & $3.73^{\mathrm{a}, \mathrm{b}}$ & $3.82^{\mathrm{a}}$ & $1.22^{\mathrm{c}}$ & $29.8^{\mathrm{d}}$ & $1.89^{\mathrm{a}, \mathrm{c}}$ & $8.80^{\mathrm{b}}$ \\
\hline $\mathrm{NH}_{4}-\mathrm{N}$ & $4.86^{\mathrm{a}, \mathrm{b}}$ & $5.32^{\mathrm{a}, \mathrm{b}}$ & $4.49^{\mathrm{b}}$ & $10.8^{\mathrm{a}, \mathrm{b}}$ & $17.9^{\mathrm{b}}$ & $6.49^{\mathrm{a}, \mathrm{b}}$ \\
\hline Org-N & $57.0^{\mathrm{a}, \mathrm{c}}$ & $78.2^{\mathrm{a}, \mathrm{b}, \mathrm{c}}$ & $39.3^{c}$ & $115^{\mathrm{a}, \mathrm{b}}$ & $83.4^{\mathrm{a}, \mathrm{b}, \mathrm{c}}$ & $123^{\mathrm{b}}$ \\
\hline Mic-N & $156^{\mathrm{a}, \mathrm{b}}$ & $185^{\mathrm{a}}$ & $203^{\mathrm{a}, \mathrm{b}}$ & $224^{\mathrm{b}}$ & $277^{\mathrm{a}}$ & $264^{\mathrm{a}}$ \\
\hline Total N & $221^{2}$ & $272^{1}$ & $248^{2}$ & $380^{2}$ & $380^{2}$ & $402^{1}$ \\
\hline
\end{tabular}

Total $\mathrm{N}$ is the sum of measured $\mathrm{N}$ species. Values are $\mu \mathrm{g} \mathrm{N} \mathrm{g}{ }^{-1}$ peat. Significant differences $(P<0.05)$ between dates at a given depth for each $\mathrm{N}$ species are indicated with different superscripted letters. Significant differences between depths at a given date for total $\mathrm{N}$ are indicated with different superscripted numbers.

between temperature and nutrient concentrations or microbial $\mathrm{CO}_{2}$ production. Temperature fluctuated more over shorter time scales than water table position (Fig. 1), and temperature on any given sampling day may not have represented longer-term conditions that could been responsible for microbial activity and nutrient status. Likewise, gravimetric moisture content, particularly in surface peat, may have fluctuated over very short time scales, explaining why water table position and not temperature or moisture content correlated with nutrient concentrations. The temperature at sampling dates was not significantly different between years, resulting from sampling on different days of year (Fig. 1). The small decrease in $\mathrm{pH}$ measured in peat slurries in 2001 compared with 2000 may have resulted from the increase in extractable DOC concentrations in 2000. Aerobic decomposition of peat results in $\mathrm{CO}_{2}$ and organic acids and secondary microbial metabolites (Verhoeven and Liefveld 1997).

Enhanced microbial $\mathrm{CO}_{2}$ production in 2001 is consistent with increased ER in 2001 relative to 2000 reported by Bubier et al. (2003) and Lafleur et al. (2003). For the months for which Lafleur et al. (2003) reported average ER values and microbial $\mathrm{CO}_{2}$ production rates were measured, temperature-corrected microbial $\mathrm{CO}_{2}$ production in the upper $30 \mathrm{~cm}$ constituted 46,41 , and $67 \%$ of ER in June 2000, August 2000, and June 2001. This suggests that increased microbial $\mathrm{CO}_{2}$ production was at least partially responsible for increased ER in 2001. Microbial $\mathrm{CO}_{2}$ production occurs as organic matter mineralization, and in absence of concomitant increased primary production, increased microbial activity may lead to a net loss of stored organic C. Alternatively, if microbial activity had not increased in 2001, we would have assumed that increased ER probably was due to increased autotrophic respiration, which would not necessarily correspond to an increased loss of stored organic C.

Although inter-seasonal nutrient and microbial variability were large, there were no consistent patterns. Williams and Silcock (2000) reported increasing microbial $\mathrm{C}$ at the end of summer coinciding with rising water tables in a UK peatland. Biomass $\mathrm{C}$ decreased again in late 
fall and early winter, in contrast to the pattern in the present study.

Many studies have used similar incubation techniques to characterize the effects of environmental changes on microbial $\mathrm{CO}_{2}$ production with samples collected at one time. Our study provides an indication of the relative magnitude of inter-seasonal and inter-annual variability within one site: We observed a doubling in microbial $\mathrm{CO}_{2}$ production over time. Glatzel et al. (2004) reported a 25-fold increase between slowest and fastest microbial $\mathrm{CO}_{2}$ production rates in eastern Canadian peatlands that underwent commercial harvesting and subsequent restoration. Microbial C and $\mathrm{N}$ only increased a maximum of 1.6- and 2-fold over time in our study, smaller than the 5- and 7-fold temporal variations reported by Williams and Silcock (2000) in a site where the water-table range was greater. In our study, the largest change in $\mathrm{N}$ was observed in the inorganic pools, which increased by up to 50- and 10-fold between 2000 and 2001. Williams et al. (1999) also reported large temporal variability, with up to 20 -fold increases in $\mathrm{NH}_{4}{ }^{+}$concentrations in moss water from a Scottish bog, though in both cases concentrations were reasonably small. Thus, although we have observed significant temporal variations in microbial and nutrient characteristics of the peat, the magnitude is small compared with previously reported variations between sites or depths.

\section{CONCLUSIONS}

Our study has demonstrated that there are significant seasonal and inter-annual differences in microbial $\mathrm{CO}_{2}$ production rates within a peat profile, particularly in the surface layers. There appeared to be a link between lower water table position and increased $\mathrm{N}$ availability, which in turn enhanced microbial $\mathrm{CO}_{2}$ production. Inter-seasonal variability in microbial $\mathrm{CO}_{2}$ production and microbial biomass $\mathrm{C}$ and $\mathrm{N}$ pools did not follow consistent patterns, which may have resulted from infrequent or inconsistent sampling, or from variations in environmental conditions. The magnitude of temporal variability for microbial $\mathrm{CO}_{2}$ production was small compared with other studies using similar techniques to illustrate effects of environmental and land use changes; however, inorganic $\mathrm{N}$ concentrations, although present in low concentrations, varied up to 50 -fold between sampling dates. Extrapolation of the incubation data showed that microbial production of $\mathrm{CO}_{2}$ can be up to half of the $\mathrm{CO}_{2}$ emitted as ER and that inter-annual changes in production potentials may partially explain increased ER in warmer, drier years. These results suggest that changes in potential microbial $\mathrm{CO}_{2}$ production and microbial community and nutrient characteristics may play an important role in controlling the emission of $\mathrm{CO}_{2}$ from terrestrial ecosystems such as peatlands.

\section{ACKNOWLEDGMENTS}

Support came from the Natural Sciences and Engineering Research Council of Canada to T.R.M. N.B. was supported by graduate fellowships from McGill University and the Centre for Climate and Global Change Research. We thank Mike Dalva (Department of Geography, McGill University) and Hélène Lalande (Department of Natural Resource Sciences, McGill University) for providing excellent technical assistance.

\section{REFERENCES}

Basiliko, N., R. Knowles, and T. R. Moore. 2004. Roles of moss species and habitats in methane consumption potential in a northern peatland. Wetlands. 24:178-185.

Blodau, C., N. Basiliko, and T. R. Moore. 2004. Carbon turnover in peatland mesocosms exposed to different water table levels. Biogeochem. 67: 331-351.

Brookes, P. C., A. Landman, G. Pruden, and D. S. Jenkinson. 1985. Chloroform fumigation and the release of soil nitrogen: A rapid direct extraction method to measure microbial biomass nitrogen in soil. Soil Biol. Biochem. 17:837-842.

Bubier, J. L., G. Bhatia, T. R. Moore, N. T. Roulet, and P. M. Lafleur. 2003. Inter-annual and inter-site variability in net ecosystem $\mathrm{CO}_{2}$ exchange controlled by respiration at a large peatland in southern Ontario, Canada. Ecosystems. 6:353-367.

Frolking, S., N. T. Roulet, T. R. Moore, P. M. Lafleur, J. L. Bubier, and P. M. Crill. 2002. Modeling seasonal to annual carbon balance of Mer Bleue Bog, Ontario, Canada. Global Biogeochem. Cycles 10.1029/2001GB001457.

Glatzel, S. N., N. Basiliko, T. R. Moore. 2004. Carbon dioxide and methane production potentials of peats from natural, harvested and restored sites, eastern Québec, Canada. Wetlands. 24:261-267.

Gorham, E. 1991. Northern peatlands: Role in the carbon cycle and probable responses to climatic warming. Ecol. Appl. 1:185-192.

Holland, E. S. and D. C. Coleman. 1987. Litter 
placement effects on microbial and organic-matter dynamics in an agroecosystem. Ecology. 68:425-433.

Lafleur, P. M., N. T. Roulet, S. W. Admiral. 2001. Annual cycle of $\mathrm{CO}_{2}$ exchange at a bog peatland. J. Geophys. Res. 106:3071-3081.

Lafleur, P. M., N. T. Roulet, J. L. Bubier, and T. R. Moore. 2003. Interannual variability in the peatland-atmosphere carbon dioxide exchange at an ombrotrophic bog. Global Biogeochem. Cycles 17\#2 10.1029/2002GB001983.

Moore, T. R., J. L. Bubier, P. M. Lafleur, S. Frolking, and N. T. Roulet. 2002. Plant biomass, production and $\mathrm{CO}_{2}$ exchange in an ombrotrophic bog. J. Ecol. 90:25-36.

Moore, T. R. and M. Dalva. 1993. The influence of temperature and water table position on carbon dioxide and methane emissions from laboratory columns of peatlands soil. J. Soil Sci. 44:651-664.

Moore, T. R. and M. Dalva. 1997. Methane and carbon dioxide exchange potentials of peat in aerobic and anaerobic laboratory incubations. Soil Biol. Biochem. 29:1157-1164.

Paul, E. A. and F. E. Clark. 1996. Soil Microbiology and Biochemistry, Second Edition. Academic Press, San Diego.

Scanlon, D. and T. R. Moore. 2000. Carbon dioxide production from peatland soil profiles: The influence of temperature, oxic/anoxic conditions and substrate. Soil Sci. 165:153-160.

Sparling, G. P., C. W. Feltham, J. Reynolds, A. W. West, and P. Singleton. 1990. Estimation of soil microbial $\mathrm{C}$ by a fumigation-extraction method: use on soils of high organic matter content and a reassessment of the $\mathrm{k}_{\mathrm{EC}}$-factor. Soil Biol. Biochem. 22:301-307.
Turunen, J., E. Tomppo, K. Tolonen, A. Reinikainen. 2002. Estimating carbon accumulation rates of undrained mires in Finland: Application to boreal and subarctic regions. Holocene. 12:69-80.

Updegraff, K., J. Pastor, S. D. Bridgham, and C. A. Johnston. 1996. Environmental and substrate controls over carbon and nitrogen mineralization in northern wetlands. Ecol. Appl. 5:151-163.

Verhoeven, J. T. A. and W. M. Liefveld. 1997. The ecological significance of organochemical compounds in Sphagnum. Acta. Bot. Neerl. 46:117-130.

Voroney, R.P., J. P. Winter, and R. P. Beyaert. 1993. Soil microbial biomass $C$ and N. In Soil Sampling and Methods of Analysis. MR Carter Ed. Lewis Publishers, Boca Raton, FL.

Williams, B., D. Silcock, and M. Young. 1999. Seasonal Dynamics of $\mathrm{N}$ in two Sphagnum moss species and the underlying peat treated with ${ }^{15} \mathrm{NH}_{4}{ }^{15} \mathrm{NO}_{3}$. Biogeochem. 45:285-302.

Williams, B. L., C. A. Shand, M. Hill, C. O'Hara, S. Smith, and M. E. Young. 1995. A procedure for the simultaneous oxidation of soluble nitrogen and phosphorus in extracts of fresh and fumigated soils and litters. Commun. Soil Sci. Plan. 26:91-106.

Williams, B. L. and D. J. Silcock. 2000. Impact of $\mathrm{NH}_{4} \mathrm{NO}_{3}$ on microbial biomass $\mathrm{C}$ and $\mathrm{N}$ and extractable DOM in raised bog peat beneath Sphagnum capillifolium and S. recurvum. Biogeochem. 49:259-276.

Yavitt, J. B., C. J. Williams, and R. K. Wieder. 1997. Production of methane and carbon dioxide in peatland ecosystems across North America: effects of temperature, aeration, and organic chemistry of peat. Geomicrobiol. J. 14:299-316. 